\title{
CRACKING THE CODE OF EASTER OR, UNDERSTANDING WHY THE DATE OF EASTER “HOPS” ALL OVER THE CALENDARS OF MARCH AND APRIL
}

\author{
Steven L. Ware ${ }^{1)^{*}}$ \\ 1) Professor of Historical Theology Nyack College, New York \\ *) Authors Correspondence: steven.ware@nyack.edu
}

\begin{abstract}
Why is it that in most years, but not every year, Western Christians--both Catholic and Protestant--celebrate Easter at least one week before Eastern (Orthodox) Christians? Furthermore, since the Bible portrays the resurrection of Jesus as occurring on the Sunday morning directly after Passover, why is it that in many years both Eastern and Western Christians celebrate Easter more than a week after Passover, or even before Passover? The major key to understanding the cycle of annual dates for Passover, Orthodox Easter, and Western Easter is the Metonic Cycle, and how it was shaped and applied in three different historical contexts. This article seeks to explore the historical genesis of the Metonic Cycle and how it was applied to each of these festivals to yield the results we see today.
\end{abstract}

Keywords: Easter, calendar, Christian, orthodox, Catholic, Protestant

Kenapa kebanyakan tahun, walaupan bukan setiap tahun, Gereja-gereja barat, yaitu gereja Katolik dan gereja Protestan, merayakan Paskah paling sedikit satu minggu sebelum Paskah Kristen Timur (gereja Ortodoks)? Selanjutnya, karena Alkitab menjelaskan kebangkitan Yesus ditentukan pada pagi hari Minggu langsung setelah Paskah Yahudi, mengapa terkadang orang-orang Kristen Timur dan orang-orang Kristen Barat merayakan Paskah lebih dari satu minggu sesudah Paskah Yahudi, ataupun sebelumnya? Kunci yang paling penting untuk mengerti putaran tanggal ini antara Paskah Yahudi, Paskah gereja Ortodoks, dan Paskah gereja Barat adalah Putaran Metonik, dan bagaimana Putaran ini dibentukan dan diterapkan dalam ketiga konteks historis. Artikel ini mau menyelidiki permulaian Putaran Metonik ini dan bagaimana Putaran ini diterapkan pada setiap festival ini sampai apa yang kita lihat hari ini.

Kata-kata kunci: Paskah, kalender, Kristen, ortodoks, Katolik, Protestan

\section{Introduction}

Most Christians will agree that every one of their gatherings for worship is at its core a celebration of Jesus' resurrection from the dead. 
Furthermore, almost all Christians will agree that Jesus' resurrection is the single-most important event in human history. Yet if asked exactly when this most important event occurred, many Christians have no clue where to begin. Some will respond that it really makes no difference when it occurred since; again, every gathering for worship is at its core a celebration of Jesus' resurrection. But this is not how early Christians thought about the matter, for within a few generations the question of precisely when to celebrate this most important event became a manysided debate which lasted for centuries. In addition, such a laissez-faire approach runs counter to human psychology: while many of us are grateful just to be alive on any given day, most of us very much appreciate having a specific birthday, which gives us specific attention on a specific day.

For most Christians today, however, the date of Easter is a rather confusing matter. In the early spring of any year, it is not uncommon for Christians to ask, "When is Easter this year?" and to wonder why Easter "hops" all around the calendars of March and April. Furthermore, it is not uncommon for Western Christians-both Catholic and Protestant-to note with no small amount of curiosity that their Orthodox Christian brethren are celebrating the resurrection of Jesus Christ on a different date-typically a week or more later in the calendar. Conversely, Christians of the Orthodox communions have wondered equally why their western brethren often celebrate this most important event a week or more "early." Christians on both sides have tended to ask their religious leaders or consult ecclesiastical texts to find out which set of dates is "correct," but usually with little success, since little has been written on the matter from either perspective which clarifies the larger picture and its historical development. ${ }^{1}$

Part of that larger picture is the Jewish feast of Passover. Biblicallyminded Christians both East and West will note that according to all four Gospels of the New Testament, Jesus' crucifixion took place on Passover $^{2}$ (Matthew 26:17; Mark 14:12; Luke 22:7; John 13:1), and his resurrection on the following Sunday morning (Matthew 28:1; Mark 16:2;

\footnotetext{
${ }^{1}$ See Bonnie Blackburn and LeofrancHolford-Strevens, The Oxford Companion to the Year: An Exploration of Calendar Customs and Time-Reckoning (Oxford: Oxford University Press, 1999), 815-816; Marcos J. Montes, "The Orthodox Ecclesiastical Calendar," http://www.smart.net/-mmontes/ortheast.html; Borgna Brunner, "A Tale of Two Easters," http://www.factmonster.com/spot/easterl.html; Astronomical Society of South Australia, "Calculate the Date of Easter Sunday,"https://www.assa.org.au/edm.

${ }^{2}$ On the question of the precise date of Jesus' crucifixion, see Steven L. Ware, When Was Jesus Really Born?: Early Christianity, the Calendar, and the Life of Jesus (Saint Louis: Concordia, 2013), 74-77; Andrew E. Steinmann, From Abraham to Paul: A Biblical Chronology (Saint Louis: Concordia, 2011), 261, 288.
} 
Luke 24:1; John 20:1). What would then appear to many a Christian as the simple answer to this dilemma is to discern whether it is Orthodox Christians or Western Christians who have followed the Biblical pattern of simply celebrating Jesus' resurrection on the Sunday following Passover. To their dismay, however, they will discover that the matter is only complicated still further, as in some years Passover occurs directly before Orthodox Easter, in some years directly before Western Easter, in some years directly before both Easters, and in some years nowhere close to either of them.

Whence this confusion of dates and the methods of computing them from one year to the next? The simple yet many-sided answer is that the annual dates of Passover, Orthodox Easter, and Western Easter flow according to three different Metonic cycles. Furthermore, it is the contention of this author that the Metonic cycle is a most fruitful avenue for understanding the calendrical relationship between these festivals, as well as the historical evolution of that relationship. In order to understand the definition, historical genesis, and dynamics of the Metonic Cycle, as well as its effects on the relative dates of Passover and both Easters, we shall begin with the ancient calendrical understanding of Passover.

\section{Passover}

One of the first indications of calendrical consciousness among the ancient Hebrews is found in God's commands to Moses in preparation for the first Passover: "This month is to be for you the first month, the first month of your year" (Exodus 12:2). A few verses later God commanded that at twilight on the fourteenth day of the same month each family was to sacrifice a year-old male lamb, spread its blood on the doorway of their homes, and roast and eat the lamb that evening. The blood of the lamb on their doorways was of course their assurance that the plague of death which was to strike every household in Egypt that night would "pass over" them. That month was Abib (Aviv), which later became known as Nisan, and 14 Nisan has been celebrated ever after by Jews worldwide as their day of divine deliverance from servitude to the Egyptians.

So when is 14 Nisan? And how does it relate to the Western (Gregorian) calendar most of us are accustomed to using most of the time? Like the earliest calendars of almost every ancient civilization, the Jewish calendar was-and still is-a lunar-based calendar. As in other early agrarian societies, most ancient Hebrews were non-literate. This is not to presume ignorance upon our ancestors, of course, but to recognize that opportunities for learning were much more limited in ancient 
societies. Since most of them were non-literate, they were somewhat dependent upon the literate elite among local or regional authorities for keeping an accurate calendar for planting and harvest times, as well as for taxation and scheduling of religious celebrations.

From an early date, the literati of nearly every ancient civilization calculated the lunar cycle (moonth, or month) at approximately 29.5 days in length. This is more than twelve times faster than the length of time required for the Earth to circumnavigate the Sun and a complete passage of the seasons. Furthermore, even the average non-literate farmer could comprehend a number of that size, and if desired could make 29 (or 30) marks on the side of their barn as a memory device. On the other hand, the length of the solar cycle at nearly 365.25 days was much more difficult to grasp. It is hence no wonder that the earliest calendars of nearly every civilization consisted of alternating blocks of twenty-nine and thirty days, for even the casual observer could ascertain that just over twelve lunar cycles (354/5 days) brought one nearly to the end of the solar cycle, or year.

While the ancients' preoccupation with the lunar calendar appears nonsensical to many moderns, it should be remembered that their most important consideration was that of properly scheduling religious celebrations. After all, one could not afford to offend the deity by forgetting their birthday, for instance - as was the case for the ancient Athenians and the birthday of their beloved Athena on 3 Skirophorion (roughly concurrent with the Summer solstice, although special sacrifices in her honor were made on the third day of every month). For the ancient Hebrews, it was equally important to celebrate the acts of God on Pesach (Passover, on 14 Nisan) and Yom Kippur (Day of Atonement, on 10 Tishrei).

But with a lunar year of 354/5 days and a solar year of 365/6 days, how were they to prevent the holidays on the lunar calendar from slowly backing up through the months of the solar calendar to ever-earlier dates-especially when the religious feasts were also tied to the planting and harvest of various crops? Numerous attempts at synchronization of lunar and solar cycles were employed by advanced ancient societies - the most accurate and successful of which became known as the Metonic Cycle. While many of their fellow Athenians reveled in the military might and cultural sophistication of their golden age in the fifth century $\mathrm{BC}$ and watched the impressive construction of temples atop the Acropolis, astronomers Meton and Euktemon and their associates contributed directly to that sophistication on the adjacent LofosNymfos (Hill of the Nymphs) by calculating that 235 lunar cycles were equivalent to nineteen solar cycles, with an overage of mere hours. In other words, they calculated that combining twelve "common" years of 
twelve lunar cycles (354/5 days) with seven "embolismic" years of thirteen lunar cycles (384/5 days) brought one back to a simultaneous beginning of both cycles. More precisely, by intercalating the extra lunar cycle in years $3,6,8,11,14,17$, and 19 of the 19-year cycle, the major religious holidays were kept in their correct months and seasons, and therefore fulfilled their intended purpose. ${ }^{3}$

It is not known exactly how early the Hebrews established their own calendar. Nor is it known exactly how early they utilized the Metonic cycle or some other form of synchronization of the lunar and solar cycles. As we have seen already, however, it is apparent that some form of detailed time reckoning was employed at least by the date of the Exodus from Egypt, whether it is dated in the fifteenth or thirteenth century BC. And a prime reason for synchronization of lunar and solar calendars was the feast of Passover, which was to take place during the first month of their religious year (seventh month of the civil year). The religious calendar was guided by the vernal equinox, which was not allowed to fall more than halfway through the month of Nisan. But the practical demands of thousands of pilgrims traveling to Jerusalem for the festival also became a key factor. No one wanted large numbers of people prevented from attending the festival because of temporal conditions. So over the years the religious leaders developed a set of qualifications which they sought before deciding whether to add an additional month before the beginning of Nisan. These included natural phenomena such as the ripening of barley and the blossoming of springtime fruit, and civil phenomena such as roads and bridges being usable for travel.

Details of the historical development of the Jewish calendar have been debated widely. What can be stated confidently, however, is that up until the third or fourth century AD there was likely no consistent pattern for intercalating extra lunar cycles into the year, but that it was done merely on an annual basis by proclamation of the Sanhedrin from Jerusalem. ${ }^{4}$ The chief problem with this practice, naturally, is that after the several diasporae of the Jews from the eighth century BC onward, a simple annual announcement from Jerusalem became increasingly inadequate, since many Jews lived too far away from Palestine to get the announcement in time and make the proper arrangements. In addition,

\footnotetext{
${ }^{3}$ Considerable debate has been generated over numerous small details of how the Greeks achieved their synchronization of lunar and solar cycles, and which years the extra lunar cycles were intercalated. See Robert Hannah, Greek and Roman Calendars: Constructions of Time in the Classical World (London: Duckworth, 2005), 55ff; Ware, 48-51.

${ }^{4}$ Ephraim Jehudah Wiesenberg asserts, for instance, that details of calendrical intercalations from one year to the next were "jealously guarded by its experts from outsiders, both Jewish and gentile." See Wiesenberg, "Calendar," Encyclopaedia Judaica (Jerusalem: Keter/Macmillan, 1978), V, 50.
} 
although the details are again a matter of debate, it is popularly asserted that Rabbi Hillel II wisely foresaw the dissolution of the Sanhedrin in the fourth century, and therefore in AD 359 established the pattern of intercalations nearly identical to that practiced for several centuries already by the Greeks in the Metonic cycle. ${ }^{5}$

The pattern presumably established by Hillel (following ancient Greek precedents) is followed in the Jewish calendar even today, with intercalations of an extra lunar cycle (embolism) in years 3, 6, 8, 11, 14, 17, and 19 of each nineteen-year cycle. The current Hebrew Metonic cycle began in 1997/8, and is scheduled to end with 2016. A new Hebrew Metonic cycle will begin in 2016/7 (at Rosh Hashonah in 2016) and extend through 2035. Extrapolating this pattern forward or backward in time and applying the pattern of embolisms allows us to project a likely calendar and date of Passover or other festivals for any given year, although it should be recognized that applying it to dates preceding Hillel II is an exercise in calendrical speculation. ${ }^{\circ}$

Worthy of historical note is the fact that the Hebrew Metonic cycle is not in sync with the Greek Metonic cycle: Although the pattern of embolisms is identical, the Hebrew cycle does not begin and end in the same years as the Greek cycle. According to the sparse knowledge we possess, it appears that the Greek Metonic cycle was likely initiated in $432 \mathrm{BC}^{7}$. But simple math tells us that if we extend the pattern of the current Hebrew Metonic cycles backward, a putative Hebrew Metonic cycle had already begun a few years earlier in 436/5 BC. Equally worthy of note-if one can tolerate a bit of calendrical speculation-is the fact that extrapolating backward another 175 Metonic cycles brings one to 3761 BC - the apparent beginning date of the Jewish Anno Mundi calendar in use today. This means that one could trace the synchronization of lunar and solar cycles into nineteen-year segments all the way back to the presumed year of creation, which conveniently occurred on the first year of a Metonic cycle. While such speculation is certainly titillating, it

${ }^{5}$ See the worthwhile treatment of this topic by Sacha Stern, Calendar and Community: A History of the Jewish Calendar, Second Century BCE to Tenth Century CE (Oxford: Oxford University Press, 2001), 2llff. Among other observations, Stern asserts that evidence of the pattern or procedure of intercalation is sporadic and incomplete among Jewish sources of the early Christian era, and that in fact Christian sources are usually more informative, although their "reliability in reporting contemporary Jewish practice can sometimes be difficult to ascertain" (49). He also admits that Christian development of Paschal cycles likely exerted some influence on rabbis of the era to solidify their own calendar (65f).

${ }^{6}$ This assumption is maintained by Hebrew calendar conversion websites, such as http://www.hebcal.com, http://www.abdicate.net, http://www.rosettacalendar.com, and http://chabad.org.

${ }^{7}$ Hannah, 55f, $85 f$. 
is doubtful that such can be traced directly to Hillel. ${ }^{8}$ Regardless, it establishes the Hebrew Metonic cycle as an entity to be considered independently of the Greek cycle. As we shall see, moreover, it is also independent of both Metonic cycles regulating the dates of the two Christian celebrations of Jesus' resurrection from the dead.

\section{Orthodox Easter}

The Metonic cycle regulating the dates of Orthodox Easter is synonymous with the Paschal cycle constructed by Dionysius Exiguus in the early sixth century - although it very possibly precedes Dionysius. It is represented in concrete form by the inscription on a marble slab located at the Museo Arcivescovilein Ravenna, Italy-certainly one of the most important artifacts of early Christian deliberations concerning the proper date of the resurrection celebration. Approximately onemeter square, the inscription includes the dates of Easter for the period AD 532-626-identical to the cycle created by Dionysius in AD 525 at the request of the papal office. ${ }^{9}$ In a circular rosette style, it is divided into nineteen sections (resembling leaves/petals) for the nineteen years of the Metonic cycle. Flowing from the cross at the center, each set of years is designated as either "common" (having twelve lunar cycles) or "embolismic" (thirteen lunar cycles). Then beginning from the outer edge, each section lists the five years of Dionysius' cycle which correspond to that stage of the Metonic cycle, and the date of Easter for each year. Likewise included are the dates of Passover and the age of the moon on Easter Sunday (figure 1). While little is known about the history of the stone itself, its very limitation to the ninety-five years of Dionysius' cycle is a sure indication that it was inscribed shortly after his creation of the cycle. In addition, the impressive physical size of this

\footnotetext{
${ }^{8}$ Alden Mosshammer contends that "no such Jewish cycle" of 19-year segments with a base date of 3761 BC "was in existence" during the lifetime of Hillel II. See The Easter Computus and the Origins of the Christian Era (Oxford: Oxford University Press, 2008), 88-89.

${ }^{9}$ Dionysius Exiguus (ca. AD 480-550) is known best as the supposed originator of the Anno Domini ("year of our Lord") dating system, which is based upon his estimation of the date of Jesus' birth. The task assigned him by the papal office, however-which provided him the occasion for recommending a new dating system-was that of constructing a new 95-year cycle of dates for Easter to replace the nearly-expired cycle of Cyril of Alexandria. The works of Dionysius are found in Patrologia Latina (J. P. Migne, ed. Paris: Montrouge, 1848), vol. LXVII. For more on Dionysius, his Paschal cycle, his construction of Anno Domini, and the numerous debates his work has engendered, see Ware, 102-116.
} 
calendar is very likely an indication of its importance-that it was displayed prominently for use by ecclesiastical authorities. ${ }^{10}$

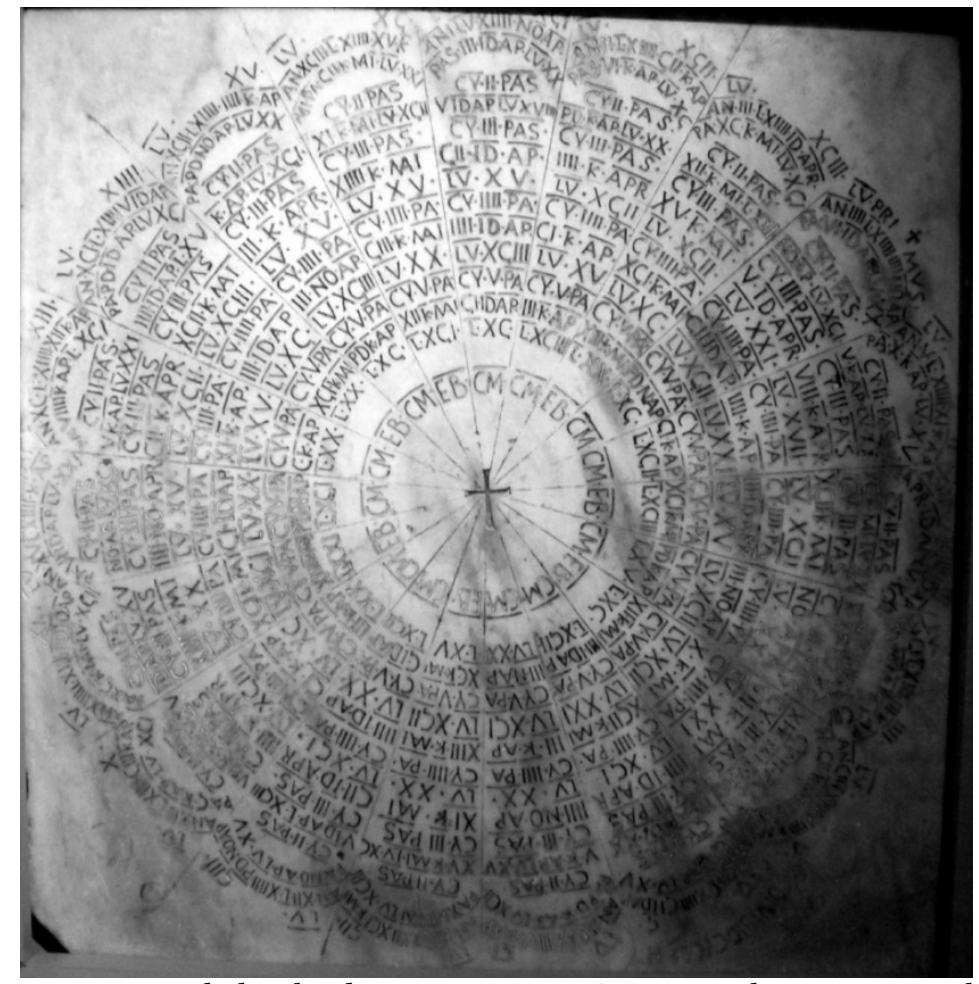

Figure l: Paschal Calendar Stone. Museo Arcivescovile; Ravenna, Italy. Photo by Author.

Careful examination of this stone shows how the Christian use of the Metonic cycle for scheduling the dates of Easter differs from the Hebrew orientation. Along the outer edge of each section is the designation of the lunar/Metonic year. The first year of the Paschal cycle (straight "up" from the top of the cross) is designated as "Luna XCL" (year 17 of the lunar/Metonic cycle). This agrees with the data in Dionysius' Liber de Paschate, where the first year of his Paschal cycle, which he designated as Anno Domini 532 (532 years since the birth of Jesus), is shown as the seventeenth year of the "circle of the moon," or

${ }^{10}$ Little information on the history of the stone is given, except that the slab came from a quarry on the island of Proconnecus in the Sea of Marmara, near the coast of modern Turkey. One travel blog described this stone as "striking but indecipherable" (http://travel-wonders.com/2009/07/07/touring-the-mosaic-city-ravenna-italy-partone/). The stone is certainly striking, but far from indecipherable, as many of this writer's students will attest. 
the Metonic cycle. ${ }^{l l}$ Furthermore, proceeding clockwise by three sections on the stone brings one to "Luna Primus," or the beginning of another Metonic cycle. Why the three-year difference between the ostensibly Christian orientation of Dionysius and the other, apparently pre-existing, cycle? While no indication is given on the stone itself or in the Paschal table of Dionysius, simple mathematical calculation by nineteen-year periods reveals that the pre-existing cycle is none other than the Hebrew Metonic cycle-beginning sixteen years prior to, or three years after, the Dionysian orientation.

So why did Dionysius create a new Metonic orientation? Indeed, it is entirely possible that Dionysius did not create the new orientation, but that it was already in use before him by Cyril of Alexandria-whose Paschal cycle covering the years AD 437-531 was superseded by that of Dionysius. ${ }^{12}$ Regardless of the identity of the creator, however, it is significant that according to this orientation a new Metonic cycle began in $1 \mathrm{BC}$ - the likely year of Jesus' birth according to the dating system propagated by Dionysius. ${ }^{13}$ Although we lack definitive support in the writings of Dionysius, that fact alone would appear to provide ample motivation for him or another Christian computist to fashion a Metonic cycle just a few years removed from that which was very possibly in use already by Jewish communities.

A further indication that this Metonic orientation was a deliberate creation by Dionysius or another Christian computistof his generation is an inscription found near the lower right corner of the slab. Just beyond the leaf representing the ninth year of the cycle (by the Dionysian orientation) is the inscription "DIVISIOCYC.LI.II" ("division of cycle 5l, part II").This means that Dionysius (or at least the author of the stone inscriptions) viewed this as the fifty-first Metonic cycle since its date of origin, and that it was a combination of an eight-year cycle with an eleven-year cycle. Curiously, if one subtracts exactly 50 Metonic cycles

${ }^{11}$ The Liber de Paschateof Dionysius is found in PL LXVII, 495ff; also at http:/hbar.phys.msu.ru.gorm/chrono /paschata.html.

${ }^{12}$ No known copy of the entire paschal cycle of Cyril survives. The final Metonic cycle (AD 513-531) is included in Dionysius' Liber de Paschate. A possible re-construction of the entire 95-year cycle of Cyril is found in Ware, 161 (Appendix B).

${ }^{13}$ A prime assertion of Mosshammer (385ff) is that Dionysius was not the author of the "Christian Era" at all, but that its origin is to be found in the early third-century Chronographiai of Sextus Julius Africanus, which was then passed down by Alexandrian scholars through the next several generations to Dionysius. Alternatively, Daniel P. McCarthy has concluded from the Paschal table of Eusebius (ca. AD 309) that he was in fact the first to deliberately identify the year of Jesus' birth and consequently to number the years from the event of the Incarnation. See McCarthy, "The emergence of Anno Domini," Time and Eternity: The Medieval Discourse (Gerhard Jaritz and Gerson Moreno-Riano, eds. Brepols: Turnhout, 2003), 52-53. 
(950 years) from AD 532-the first year of Dionysius' paschal cycle - the result is $419 \mathrm{BC} \cdot{ }^{14}$ As noted already, this is the period during which Greek astronomer Meton and his associates in Athens designed the cycle which still bears his name.

Neither in his Argumenta Paschalianor in his introductory letter to a papal representative by the name of Petronius does Dionysius make specific mention of the Greek Metonic cycle, from which his own cycle differs by thirteen years (if extended backward to a putative beginning in $419 \mathrm{BC}$, or by six years if extended backward one more cycle to a beginning in $438 \mathrm{BC}$ ). Nor does he mention the Hebrew Metonic cycle, from which his own cycle differs by three years. Nor does he give specific mention of a fifty-first Metonic cycle, or of how many cycles have preceded his own beginning with the year he identified as AD 532. It is therefore quite possible that the source of the information in the inscription is someone other than Dionysius. Regardless of the author's identity, however, this stone inscription tells us that Christian computists of the early sixth century were aware of the approximate number of years since the genesis of the Greek Metonic cycle. Secondly, it tells us that they were equally aware of the Hebrew Metonic cycle and its orientation.

\section{Western Easter}

The Orthodox Christian calendar and its calculation of the annual date of Easter have remained essentially unchanged from the sixth century to the present, in spite of numerous suggestions from both ecclesiastical and scientific sources, and debates within Orthodoxy itself. The same cannot be said, however, for "Western" Christians, both Catholic and Protestant. The calendrical revision officialized by Pope Gregory XIII in 1582 resulted in the secular business calendar utilized by virtually the entire world today. But a prime motivation for the revision was the accurate calculation of the Easter celebration.

It had been recognized by astronomers and computists for centuries that the Julian calendar (constructed under the administration of Julius Caesar and implemented in 45 BC) was slightly incorrect in its estimation of the length of the solar year. The true length of the year was not the Julian estimate of 365.25 days, but eleven minutes and fifteen seconds shorter-which would appear insignificant in the course of a

14 This is a slight correction of my statement in "Die Ostersteintafeln: Steininschriften der Osterkalender der späten Antike und des späten Mittelalters" in Mittelalterliche Astronomische Gro] 2012 (Manfred Schukowski, Uta Jahnke, und Wolfgang Fehlberg, Hg. Leipzig: AkademischeVerlagsanstalt, 2014), 69. 
single year but added up to about three days and three hours in the course of 400 years. The result-as verified by astronomers linked to the Papal Curia in the sixteenth century-was that the true vernal equinox had slipped backward by at least ten days from the assumed date of 21 March. ${ }^{15}$ This naturally raised a problem for the calculation of the annual date of Easter, as well as raising a problem regarding the integrity of the Catholic Church. After all, how could the church claim to be the vicar of Christ and the repository of all truth if it could not even keep an accurate calendar?

Following an initiative made by the reforming council of Trent (1545-1563), a papal commission made recommendations in 1575, followed by further recommendations in 1581, which resulted in Gregory's Inter Gravissimus of 24 February 1582. The most immediate concern was the correction of the ten-day overage accumulated by the calendar since it had been recalculated at the time of the Council of Nicea in the fourth century. This was affected by eliminating ten days from the following October-proclaiming that the day immediately following 4 October 1582 was to be regarded as 15 October, not 5 October. Secondly, since the overage of eleven minutes and fifteen seconds each year accumulated to just over three days in the course of 400 years, it was proclaimed that no leap year day would be inserted in the centennial years (those years at the end of every century ending in "_00") unless that year were divisible by 400 . That meant the approaching end of their own sixteenth century (AD 1600) would indeed be a leap year, since 1,600 is divisible by 400 . It would appear that they left it to a later generation to remember that the successive centennial years of 1700, 1800, and 1900 were not to be regarded as leap years, in order to keep the ancient error from creeping back into the calendar. ${ }^{16}$

As we should only expect in that era of sharp political and ecclesiastical rivalries, it was inevitable that not everyone would immediately agree with and apply the Gregorian reform. As expected, Catholic bishops and local clergy complied with little delay, as did Catholic monarchs in Spain, Portugal, France, Belgium, Poland, and Italy. In many Protestant regions, on the other hand, the new calendar was met with suspicion as a kind of papal imposition on lands where his decrees no longer held sway. Yet because Protestants generally welcomed the

\footnotetext{
${ }^{15}$ For more on the construction of Gregory's calendar and its gradual adoption by numerous nations, see Ware, 130-134; David Ewing Duncan, The Calendar: Humanity's Epic Struggle to Determine a True and Accurate Year (London: Fourth Estate, 1999), $288 \mathrm{ff}$.

${ }^{16}$ For the text of Gregory's Inter Gravissimusin Latin, French, and English, see http://www.bluewaterarts.com/calendar/NewInterGravissimus.htm.
} 
Copernican astronomical system and other scientific findings of the era, it was not long until this became viewed as a non-theological matter.

Not surprisingly, the Gregorian calendar faced even more resistance in the Orthodox dominions, as an unintended consequence of the reform was to furnish one more reason for alienation between Eastern and Western Christians. Officially separated since the mutual condemnations of 1054, the papal representatives sent to Constantinople in the wake of Gregory's proclamation could hardly have entertained much optimism over the reception their new calendar would likely encounter. Predictably, although their report was received graciously, and even though Orthodox theologians were equally aware of the need for calendrical reform, Gregory's calendar was rejected because it would require altering the traditionally understood method for calculating the date of Easter. ${ }^{17}$

So what was altered-other than the elimination of the ten days in October and three leap days in every 400 years? As shown on Appendix A below, the elimination of ten days from October 1582 forced an adjustment in the effective dates of Easter for the remainder of that Metonic cycle (\#106, as numbered from the putative beginning of the first Metonic cycle in $419 \mathrm{BC}$, according to the inscription on the paschal calendar at Ravenna). Consequently, adjustment of the dates of Easter then forced an adjustment of the embolisms within that nineteen-year cycle. The final thirteen years of Metonic Cycle \#106 (1583-1595) were therefore a period of transition, with the result that only six embolisms were required within the entire nineteen-year period rather than the usual seven-in years 3, 6, 9, 12, 14, and 17 (1579, 1582, 1585, 1588, 1590, and 1593). But it also required that the next Metonic cycle begin with an embolismic year (1596) in order to keep the date of Easter within the limits already established.

The result is shown in the new pattern of common and embolismic years beginning with Metonic Cycle \#107. For “Western” Christians, Catholic and Protestant alike, since 1596 the embolisms have occurred in years $1,4,6,9,12,15$, and 17 of the cycle. So while both Eastern and Western Christians even today mark the beginning of a new Metonic cycle with the same year (e.g., 1995, 2014, 2033, etc.), the difference in the

\footnotetext{
${ }^{17}$ Even more than three centuries later, when the Orthodox religious calendar was adjusted to agree with the Gregorian calendar by a reforming council in 1923, many Russian priests discovered to their dismay that it motivated full-scale parish revoltsperhaps a reaction to the social and political makeover of Russian life by the Bolsheviks. Whatever the reason, the reform was short-lived. Consequently, most Russian Orthodox believers still follow the Julian calendar for ecclesiastical purposes, while operating on the Gregorian calendar outside the church. See Marcos J. Montes, "The Orthodox Ecclesiastical Calendar,"http://www.smart.net/-mmontes/ortheast.html.
} 
patterns of common and embolismic years causes a difference in the dates of Easter in most years-regardless of whether Orthodox Christians ever adopt the modern Gregorian dates. So while the wording of Gregory's proclamation made it clear that this action was intended as an act of faithfulness to the words of Scripture and apostolic practiceand therefore much more than a mere improvement of the calendar-it was clear that not all Christians agreed that this was the correct way to perceive the hand of God in human history.

The modern result of these historical developments is seen on Appendix B below. Using the recently expired Metonic cycle ( $\$ 128$, AD 1995-2013) and the current Metonic cycle ( $¥ 129$, AD 2014-2032) as examples, and combining them with a putative Hebrew Metonic cycle (\#128-130) for the same years, the modern relationship between Passover, Orthodox Easter, and Western Easter becomes clearer. The Hebrew Metonic cycle for Passover-perhaps to be traced back to Rabbi Hillel II in the fourth century-begins sixteen years ahead of (or, perhaps three years behind) the Metonic cycle for both Christian calculations of Easter. And while the two Christian Metonic cycles begin concurrently, their respective celebrations of Jesus' resurrection usually occur on different dates because 1) most Orthodox communions still use the Julian calendar for ecclesiastical purposes, and 2) Orthodox and Western Christians do not utilize the same pattern of common and embolismic years.

Consequently, in some years-such as 2014-it appears that all is well in the Judeo-Christian world, as Passover (14 April) occurs just a few days before Easter, and both Orthodox and Western Christians celebrate Easter on the same date (20 April). In many other years, however-such as 2015-Passover (3 April) occurs directly before Western Easter (5 April), while Orthodox Easter (12 April) is a week later and therefore apparently out of sync. And in still other years-such as 2016-Passover (22 April) is not directly before either Orthodox Easter (1 May) or Western Easter (27 March).And in a year like 2016 Western Christians might even be tempted to question whether their Easter date is at all legitimate, since it occurs well before the date of Passover. A correct understanding of the differing Metonic cycles and their historical development, however, shows that this is a simple fault of the cycles themselves and not a calendrical miscalculation-let alone an anti-Jewish bias on the part of Christians.

A more common reaction of Christians to this information is one of bewilderment and frustration: "Why can't we simplify the whole matter and just say that Easter will always be, for instance, on the first Sunday of April?" Proposals of this type have been, not surprisingly, topics of serious deliberation in recent years by a number of church bodies and 
ecumenical agencies. The likelihood that all Christian church bodies would agree to such a proposal, however, is rather slim.

Alternatively, biblically- and historically-minded Christians will sometimes ask, "So what was the actual calendar date of Jesus' resurrection from the dead? (...or the date of his crucifixion)? ... Why can't we just celebrate every year on that day?" The most likely solar calendar date that satisfies this query is 5 April AD 33 (according to the Julian calendar used by the Romans at the time). ${ }^{18}$ While this sounds like an obvious answer to modern minds, however, this is not how any of the early Christian theologians and computists answered the question. As we have seen already, in all four Gospels and the writings of early Christian leaders the beginning point for scheduling the date of Easter was the date of Passover.

In other words, although many of the early Christian writers were probably very familiar with the Julian calendar and could have verified that Jesus' resurrection from the dead occurred on 5 April AD 33, every one of them who took up this question worked rather from the assumption that the celebration of Jesus' resurrection was to be scheduled in conjunction with Passover-meaning that in deciding this matter the lunar-based Hebrew calendar was to take precedence over the solar-based Julian calendar. While that answer may not sit well with many Christians in the twenty-first century, it should perhaps push us beyond our comfort zone toward an understanding of the thought world of early Christians.

Appendix A

Metonic Cycles \$106 (1577-1595) and $\$ 107$ (1596-1614)

\begin{tabular}{|c|c|c|c|c|c|}
\hline Year & $\begin{array}{l}\text { Year in } \\
\text { Metonic } \\
\text { Cycle }\end{array}$ & $\begin{array}{l}\text { Julian (Orthodox) Easter } \\
\text { Date } \\
\text { (Julian/Gregorian beginning } \\
\text { 1583) }\end{array}$ & $\begin{array}{c}\text { Julian Computistical } \\
\text { Data }\end{array}$ & $\begin{array}{c}\text { Gregorian } \\
\text { (Western) Easter } \\
\text { Date }\end{array}$ & $\begin{array}{c}\text { Gregorian } \\
\text { Computistical } \\
\text { Data }\end{array}$ \\
\hline 1577 & $\mathrm{l}$ & 7 April & $\mathrm{Cm}$ & & \\
\hline 1578 & 2 & 30 March & $\begin{array}{l}-8 \\
\mathrm{Cm}\end{array}$ & & \\
\hline 1579 & 3 & 19 April & $\begin{array}{l}+20 \\
\mathrm{Emb}\end{array}$ & & \\
\hline 1580 & 4 & 3 April & $\begin{array}{l}-16 \\
\mathrm{Cm} \\
\mathrm{Ly}\end{array}$ & & \\
\hline 1581 & 5 & 26 March & $\begin{array}{l}-8 \\
C m \\
C m\end{array}$ & & \\
\hline 1582 & 6 & 15 April & $\begin{array}{l}+20 \\
\mathrm{Emb}\end{array}$ & & \\
\hline 1583 & 7 & 31 March/10 April & $\begin{array}{l}15 \\
\mathrm{Cm}\end{array}$ & 10 April & $\begin{array}{l}-5 \\
\mathrm{Cm}\end{array}$ \\
\hline
\end{tabular}

${ }^{18}$ For more on this calendar date and its connection to the resurrection of Jesus, see Ware, 74-79; Steinmann, 285-287; Colin J. Humphreys and W. G. Waddington, "Astronomy and the Date of the Crucifixion," Chronos, Kairos, Christos (Jerry Vardaman and Edwin M. Yamauchi, eds. Winona Lake, IN: Eisenbrauns, 1989), 172-179. For more on early Christian deliberations concerning the proper date for celebrating Jesus' resurrection, see Ware, $85 \mathrm{ff}$. 


\begin{tabular}{|c|c|c|c|c|c|}
\hline 1584 & 8 & 19 April/29 April & $\begin{array}{c}+20 \\
\mathrm{Emb} \\
\mathrm{Ly}\end{array}$ & l April & $\begin{array}{c}-9 \\
\mathrm{Cm} \\
\mathrm{Ly}\end{array}$ \\
\hline 1585 & 9 & 11 April/2l April & $\begin{array}{c}-8 \\
\mathrm{Cm} \\
\end{array}$ & 2l April & $\begin{array}{r}+20 \\
\text { Emb } \\
\end{array}$ \\
\hline 1586 & 10 & 3 April/13 April & $\begin{array}{c}-8 \\
\mathrm{Cm} \\
\end{array}$ & 6 April & $\begin{array}{l}-15 \\
\mathrm{Cm} \\
\end{array}$ \\
\hline 1587 & 11 & 16 April/26 April & $\begin{array}{c}+13 \\
\text { Emb }\end{array}$ & 29 March & $\begin{array}{c}-8 \\
\mathrm{Cm}\end{array}$ \\
\hline 1588 & 12 & 7 April/17 April & $\begin{array}{l}-9 \\
\mathrm{Cm} \\
\mathrm{Ly}\end{array}$ & 17 April & $\begin{array}{c}+19 \\
\text { Emb } \\
\text { Ly }\end{array}$ \\
\hline 1589 & 13 & $30 \mathrm{March} / 9$ April & $\begin{array}{c}-8 \\
\mathrm{Cm}\end{array}$ & 2 April & $\begin{array}{l}-15 \\
\mathrm{Cm}\end{array}$ \\
\hline 1590 & 14 & 19 April/29 April & $\begin{array}{l}+20 \\
\text { Emb } \\
\end{array}$ & 22 April & $\begin{array}{l}+20 \\
\text { Emb }\end{array}$ \\
\hline 1591 & 15 & 4 April/14 April & $\begin{array}{r}15 \\
\mathrm{Cm} \\
\end{array}$ & 14 April & $\begin{array}{c}-8 \\
\mathrm{Cm} \\
\end{array}$ \\
\hline 1592 & 16 & $26 \mathrm{March} / 5$ April & $\begin{array}{l}-9 \\
\mathrm{Cm} \\
\text { Ly }\end{array}$ & $29 \mathrm{March}$ & $\begin{array}{l}-16 \\
\mathrm{Cm} \\
\mathrm{Ly}\end{array}$ \\
\hline 1593 & 17 & 15 April/25 April & $\begin{array}{l}+20 \\
\text { Emb }\end{array}$ & 18 April & $\begin{array}{c}+20 \\
\text { Emb }\end{array}$ \\
\hline 1594 & 18 & 31 March/10 April & $\begin{array}{r}-15 \\
\mathrm{Cm}\end{array}$ & 10 April & $\begin{array}{c}-8 \\
\mathrm{Cm}\end{array}$ \\
\hline 1595 & 19 & 20 April/30 April & $\begin{array}{l}+20 \\
\text { Emb }\end{array}$ & 26 March & $\begin{array}{l}-15 \\
\mathrm{Cm}\end{array}$ \\
\hline 1596 & 1 & 11 April/2l April & $\begin{array}{c}-9 \\
\mathrm{Cm} \\
\mathrm{Ly}\end{array}$ & 14 April & $\begin{array}{c}+19 \\
\text { Emb } \\
\text { Ly }\end{array}$ \\
\hline 1597 & 2 & 27 March/6 April & $\begin{array}{r}15 \\
\mathrm{Cm} \\
\end{array}$ & 6 April & $\begin{array}{c}-8 \\
\mathrm{Cm}\end{array}$ \\
\hline 1598 & 3 & 16 April/26 April & $\begin{array}{l}+20 \\
\text { Emb }\end{array}$ & 22 March & $\begin{array}{c}-15 \\
\mathrm{Cm} \\
\end{array}$ \\
\hline 1599 & 4 & 8 April/18 April & $\begin{array}{c}-8 \\
\mathrm{Cm} \\
\end{array}$ & 11 April & $\begin{array}{l}+20 \\
\text { Emb } \\
\end{array}$ \\
\hline 1600 & 5 & $23 \mathrm{March} / 2$ April & $\begin{array}{l}-16 \\
\mathrm{Cm} \\
\mathrm{Ly}\end{array}$ & 2 April & $\begin{array}{c}-9 \\
\mathrm{Cm} \\
\mathrm{Ly}\end{array}$ \\
\hline 1601 & 6 & 12 April/22 April & $\begin{array}{r}+20 \\
\text { Emb } \\
\end{array}$ & 22 April & $\begin{array}{r}+20 \\
\text { Emb } \\
\end{array}$ \\
\hline 1602 & 7 & 4 April/14 April & $\begin{array}{c}-8 \\
\mathrm{Cm} \\
\end{array}$ & 7 April & $\begin{array}{l}-15 \\
\mathrm{Cm} \\
\end{array}$ \\
\hline 1603 & 8 & 24 April/4 Mai & $\begin{array}{l}+20 \\
\text { Emb }\end{array}$ & 30 March & $\begin{array}{c}-8 \\
\mathrm{Cm} \\
\end{array}$ \\
\hline 1604 & 9 & 8 April/18 April & $\begin{array}{l}-16 \\
\mathrm{Cm} \\
\mathrm{Ly}\end{array}$ & 18 April & $\begin{array}{c}+19 \\
\text { Emb } \\
\text { Ly }\end{array}$ \\
\hline 1605 & 10 & 31 March/10 April & $\begin{array}{c}-8 \\
\mathrm{Cm} \\
\end{array}$ & 10 April & $\begin{array}{l}-8 \\
\mathrm{Cm}\end{array}$ \\
\hline 1606 & 11 & 20 April/30 April & $\begin{array}{l}+20 \\
\text { Emb }\end{array}$ & $26 \mathrm{March}$ & $\begin{array}{r}-15 \\
\mathrm{Cm} \\
\end{array}$ \\
\hline 1607 & 12 & 5 April/15 April & $\begin{array}{r}15 \\
\mathrm{Cm}\end{array}$ & 15 April & $\begin{array}{l}+20 \\
\text { Emb }\end{array}$ \\
\hline 1608 & 13 & $27 \mathrm{March} / 6$ April & $\begin{array}{c}-9 \\
\mathrm{Cm} \\
\mathrm{Ly}\end{array}$ & 6 April & $\begin{array}{c}-9 \\
\mathrm{Cm} \\
\mathrm{Ly}\end{array}$ \\
\hline 1609 & 14 & 16 April/26 April & $\begin{array}{l}+20 \\
\text { Emb }\end{array}$ & 19 April & $\begin{array}{c}+13 \\
\text { Emb }\end{array}$ \\
\hline 1610 & 15 & 8 April/18 April & $\begin{array}{c}-8 \\
\mathrm{Cm}\end{array}$ & 11 April & $\begin{array}{c}-8 \\
\mathrm{Cm}\end{array}$ \\
\hline 1611 & 16 & $24 \mathrm{March} / 3$ April & $\begin{array}{l}-15 \\
\mathrm{Cm} \\
\end{array}$ & 3 April & $\begin{array}{c}-8 \\
\mathrm{Cm} \\
\end{array}$ \\
\hline 1612 & 17 & 12 April/22 April & $\begin{array}{c}+19 \\
\text { Emb } \\
\text { Ly }\end{array}$ & 22 April & $\begin{array}{c}+19 \\
\text { Emb } \\
\text { Ly }\end{array}$ \\
\hline 1613 & 18 & 4 April/14 April & $\begin{array}{c}-8 \\
\mathrm{Cm}\end{array}$ & 7 April & $\begin{array}{r}-15 \\
\mathrm{Cm}\end{array}$ \\
\hline 1614 & 19 & $24 \mathrm{April} / 4 \mathrm{Mai}$ & $\begin{array}{l}+20 \\
\text { Emb }\end{array}$ & 30 March & $\begin{array}{l}-8 \\
\mathrm{Cm} \\
\end{array}$ \\
\hline 1615 & 1 & 9 April/19 April & $\begin{array}{l}15 \\
\mathrm{Cm} \\
\end{array}$ & 19 April & $\begin{array}{l}+20 \\
\text { Emb }\end{array}$ \\
\hline
\end{tabular}


Appendix B

Metonic Cycles \$128-12AD 1995-2032

\begin{tabular}{|c|c|c|c|c|c|c|c|}
\hline $\begin{array}{c}\text { Metonic \# } \\
\text { Hebrew } \\
\text { Christian }\end{array}$ & $\begin{array}{l}\text { Hebrew Year/ } \\
\text { Gregorian Year }\end{array}$ & $\begin{array}{l}\text { Passover } \\
\text { Date }\end{array}$ & $\begin{array}{c}\text { Passover } \\
\text { Computistic } \\
\text { Data }\end{array}$ & $\begin{array}{c}\text { Orthodox } \\
\text { (Dionysian) } \\
\text { Easter Date }\end{array}$ & $\begin{array}{c}\text { Orthodox } \\
\text { Computistic } \\
\text { Data }\end{array}$ & $\begin{array}{c}\text { Western } \\
\text { (Catholic) } \\
\text { Easter Date }\end{array}$ & $\begin{array}{c}\text { Western } \\
\text { Computistic Data }\end{array}$ \\
\hline $128 / 17128 / 1$ & $5755 / 1995$ & 14 April & $+19 /+384 / \mathrm{Em}$ & 23 April & $-8 / \mathrm{Cm}$ & 16 April & $+13 / \mathrm{Em}$ \\
\hline $\begin{array}{l}128 / 18 \\
128 / 2\end{array}$ & $5756 / 1996$ & 3 April & $-11 /+355 / \mathrm{Cm}$ & 14 April & $\begin{array}{c}-9 / \mathrm{Cm} \\
\mathrm{Ly}\end{array}$ & 7 April & $\begin{array}{c}-9 / \mathrm{Cm} \\
\mathrm{Ly}\end{array}$ \\
\hline $128 / 19128 / 3$ & $5757 / 1997$ & 21 April & $+18 /+383 / \mathrm{Em}$ & 27 April & $+13 / \mathrm{Em}$ & 30 March & $-8 / \mathrm{Cm}$ \\
\hline $\begin{array}{l}129 / 1 \\
128 / 4\end{array}$ & $5758 / 1998$ & 10 April & $-11 /+354 / C m$ & 19 April & $-8 / \mathrm{Cm}$ & 12 April & $+13 / E m$ \\
\hline $\begin{array}{l}129 / 2 \\
128 / 5\end{array}$ & $5759 / 1999$ & 31 March & $-10 /+355 \mathrm{Cm}$ & 11 April & $-8 / \mathrm{Cm}$ & 4 April & $-8 / \mathrm{Cm}$ \\
\hline $\begin{array}{l}129 / 3 \\
128 / 6\end{array}$ & $5760 / 2000$ & 19 April & $+19 /+385 / E m$ & 30 April & $\begin{array}{l}+19 / \mathrm{Em} \\
\text { Ly }\end{array}$ & 23 April & $\begin{array}{c}+19 / \mathrm{Em} \\
\mathrm{Ly}\end{array}$ \\
\hline $\begin{array}{l}129 / 4 \\
128 / 7\end{array}$ & $5761 / 2001$ & 7 April & $-12 /+353 / \mathrm{Cm}$ & 15 April & $-15 / \mathrm{Cm}$ & 15 April & $-8 / \mathrm{Cm}$ \\
\hline $\begin{array}{l}129 / 5 \\
128 / 8\end{array}$ & $5762 / 2002$ & 27 March & $-1 \mathrm{l} /+354 / \mathrm{Cm}$ & 5 May & $+20 / \mathrm{Em}$ & 31 March & $-15 / \mathrm{Cm}$ \\
\hline $\begin{array}{l}129 / 6 \\
128 / 9\end{array}$ & $5763 / 2003$ & 16 April & $+20 /+385 / \mathrm{Em}$ & 27 April & $-8 / \mathrm{Cm}$ & 20 April & $+20 / \mathrm{Em}$ \\
\hline $\begin{array}{c}129 / 7 \\
128 / 10\end{array}$ & $5764 / 2004$ & 5 April & $-1 \mathrm{l} /+355 / \mathrm{Cm}$ & 11 April & $\begin{array}{c}-16 / \mathrm{Cm} \\
\mathrm{Ly}\end{array}$ & 11 April & $\begin{array}{c}-9 / \mathrm{Cm} \\
\mathrm{Ly}\end{array}$ \\
\hline $\begin{array}{l}129 / 8 \\
128 / 11\end{array}$ & $5765 / 2005$ & 23 April & $+18 /+383 / E m$ & 1 May & $+20 / \mathrm{Em}$ & 27 March & $-15 / \mathrm{Cm}$ \\
\hline $\begin{array}{l}129 / 9 \\
128 / 12\end{array}$ & $5766 / 2006$ & 12 April & $-1 \mathrm{l} /+354 / \mathrm{Cm}$ & 23 April & $-8 / \mathrm{Cm}$ & 16 April & $+20 / \mathrm{Em}$ \\
\hline $\begin{array}{l}129 / 10 \\
128 / 13\end{array}$ & $5767 / 2007$ & 2 April & $-10 /+355 / \mathrm{Cm}$ & 8 April & $-15 / \mathrm{Cm}$ & 8 April & $-8 / \mathrm{Cm}$ \\
\hline $\begin{array}{l}129 / 11 \\
128 / 14\end{array}$ & $5768 / 2008$ & 19 April & $+17 /+383 / E m$ & 27 April & $\begin{array}{c}+19 / \text { Em } \\
\text { Ly }\end{array}$ & $23 \mathrm{March}$ & $\begin{array}{c}-16 / \mathrm{Cm} \\
\mathrm{Ly}\end{array}$ \\
\hline $\begin{array}{l}129 / 12 \\
128 / 15\end{array}$ & $5769 / 2009$ & 8 April & $-1 \mathrm{l} /+354 / \mathrm{Cm}$ & 19 April & $-8 / \mathrm{Cm}$ & 12 April & $+20 / E m$ \\
\hline $\begin{array}{l}129 / 13 \\
128 / 16\end{array}$ & $5770 / 2010$ & 29 March & $-10 /+355 / \mathrm{Cm}$ & 4 April & $-15 / \mathrm{Cm}$ & 4 April & $-8 / \mathrm{Cm}$ \\
\hline $\begin{array}{l}129 / 14 \\
128 / 17\end{array}$ & $5771 / 2011$ & 18 April & $+20 /+385 / \mathrm{Em}$ & 24 April & $+20 / \mathrm{Em}$ & 24 April & $+20 / \mathrm{Em}$ \\
\hline $\begin{array}{l}129 / 15 \\
128 / 18\end{array}$ & $5772 / 2012$ & 6 April & $-12 /+354 / \mathrm{Cm}$ & 15 April & $\begin{array}{l}-9 / \mathrm{Cm} \\
\mathrm{Ly}\end{array}$ & 8 April & $\begin{array}{c}-16 / \mathrm{Cm} \\
\mathrm{Ly}\end{array}$ \\
\hline $\begin{array}{l}129 / 16 \\
128 / 19\end{array}$ & $5773 / 2013$ & 25 March & $-12 /+354 / \mathrm{Cm}$ & 5 May & $+20 / \mathrm{Em}$ & 31 March & $-8 / \mathrm{Cm}$ \\
\hline $\begin{array}{l}129 / 17 \\
129 / 1\end{array}$ & $5774 / 2014$ & 14 April & $+20 /+385 / \mathrm{Em}$ & 20 April & $-15 / \mathrm{Cm}$ & 20 April & $+20 / \mathrm{Em}$ \\
\hline $\begin{array}{l}129 / 18 \\
129 / 2\end{array}$ & $5775 / 2015$ & 3 April & $-1 \mathrm{l} /+354 / \mathrm{Cm}$ & 12 April & $-8 / \mathrm{Cm}$ & 5 April & $-15 / \mathrm{Cm}$ \\
\hline $\begin{array}{l}129 / 19 \\
129 / 3\end{array}$ & $5776 / 2016$ & 22 April & $+19 /+385 / \mathrm{Em}$ & 1 May & $\begin{array}{c}+19 / \mathrm{Em} \\
\mathrm{Ly}\end{array}$ & 27 March & $\begin{array}{c}-8 / \mathrm{Cm} \\
\mathrm{Ly}\end{array}$ \\
\hline $\begin{array}{l}130 / 1 \\
129 / 4 \\
\end{array}$ & $5777 / 2017$ & 10 April & $-12 /+353 / \mathrm{Cm}$ & 16 April & $-15 / \mathrm{Cm}$ & 16 April & $+20 / \mathrm{Em}$ \\
\hline $\begin{array}{l}130 / 2 \\
129 / 5\end{array}$ & $5778 / 2018$ & 30 March & $-11 /+354 / \mathrm{Cm}$ & 8 April & $-8 / \mathrm{Cm}$ & l April & $-15 / \mathrm{Cm}$ \\
\hline $\begin{array}{l}130 / 3 \\
129 / 6\end{array}$ & $5779 / 2019$ & 19 April & $+20 /+385 / E m$ & 28 April & $+20 / \mathrm{Em}$ & 2l April & $+20 / E m$ \\
\hline $\begin{array}{l}130 / 4 \\
129 / 7\end{array}$ & $5780 / 2020$ & 8 April & $-1 \mathrm{l} /+355 / \mathrm{Cm}$ & 19 April & $\begin{array}{c}-9 / \mathrm{Cm} \\
\mathrm{Ly}\end{array}$ & 12 April & $\begin{array}{c}-9 / \mathrm{Cm} \\
\mathrm{Ly}\end{array}$ \\
\hline $\begin{array}{l}130 / 5 \\
129 / 8\end{array}$ & $5781 / 2021$ & 27 March & $-12 /+353 / \mathrm{Cm}$ & 2 May & $+13 / E m$ & 4 April & $-8 / \mathrm{Cm}$ \\
\hline $\begin{array}{l}130 / 6 \\
129 / 9\end{array}$ & $5782 / 2022$ & 15 April & $+19 /+384 / \mathrm{Em}$ & 24 April & $-8 / \mathrm{Cm}$ & 17 April & $+13 / E m$ \\
\hline $\begin{array}{c}130 / 7 \\
129 / 10\end{array}$ & $5783 / 2023$ & 5 April & $-10 /+355 / \mathrm{Cm}$ & 16 April & $-8 / \mathrm{Cm}$ & 9 April & $-8 / \mathrm{Cm}$ \\
\hline $\begin{array}{l}130 / 8 \\
129 / 11\end{array}$ & $5784 / 2024$ & 22 April & $+17 /+383 / E m$ & 5 May & $\begin{array}{c}+19 / \mathrm{Em} \\
\mathrm{Ly}\end{array}$ & 31 March & $\begin{array}{c}-9 / \mathrm{Cm} \\
\mathrm{Ly}\end{array}$ \\
\hline $\begin{array}{l}130 / 9 \\
129 / 12\end{array}$ & $5785 / 2025$ & 12 April & $-10 /+355 / \mathrm{Cm}$ & 20 April & $-15 / \mathrm{Cm}$ & 20 April & $+20 / \mathrm{Em}$ \\
\hline $\begin{array}{l}130 / 10 \\
129 / 13\end{array}$ & $5786 / 2026$ & 1 April & $-1 \mathrm{l} /+354 / \mathrm{Cm}$ & 12 April & $-8 / \mathrm{Cm}$ & 5 April & $-15 / \mathrm{Cm}$ \\
\hline $\begin{array}{l}130 / 11 \\
129 / 14\end{array}$ & $5787 / 2027$ & 2l April & $+20 /+385 / \mathrm{Em}$ & 2 May & $+20 / \mathrm{Em}$ & $28 \mathrm{March}$ & $-8 / \mathrm{Cm}$ \\
\hline $\begin{array}{l}130 / 12 \\
129 / 15\end{array}$ & $5788 / 2028$ & 10 April & $-11 /+355 / \mathrm{Cm}$ & 16 April & $\begin{array}{c}-16 / \mathrm{Cm} \\
\mathrm{Ly}\end{array}$ & 16 April & $\begin{array}{c}+19 / \mathrm{Em} \\
\mathrm{Ly}\end{array}$ \\
\hline $\begin{array}{l}130 / 13 \\
129 / 16\end{array}$ & $5789 / 2029$ & 30 March & $-1 \mathrm{l} /+354 / \mathrm{Cm}$ & 8 April & $-8 / \mathrm{Cm}$ & 1 April & $-15 / \mathrm{Cm}$ \\
\hline $\begin{array}{l}130 / 14 \\
129 / 17\end{array}$ & $5790 / 2030$ & 17 April & $+18 /+383 / \mathrm{Em}$ & 28 April & $+20 / \mathrm{Em}$ & 2l April & $+20 / E m$ \\
\hline $\begin{array}{l}130 / 15 \\
129 / 18\end{array}$ & $5791 / 2031$ & 7 April & $-10 /+355 / \mathrm{Cm}$ & 13 April & $-15 / \mathrm{Cm}$ & 13 April & $-8 / \mathrm{Cm}$ \\
\hline $\begin{array}{l}130 / 16 \\
129 / 19\end{array}$ & $5792 / 2032$ & 26 March & $-12 /+354 / \mathrm{Cm}$ & 2 May & $\begin{array}{c}+19 / \mathrm{Em} \\
\mathrm{Ly}\end{array}$ & $28 \mathrm{March}$ & $\begin{array}{c}-16 / \mathrm{Cm} \\
\mathrm{Ly}\end{array}$ \\
\hline
\end{tabular}




\section{Bibliography}

Astronomical Society of South Australia. "Calculate the Date of Easter Sunday." Accessed 25 May 2014, https://www.assa.org.au/edm

Blackburn, Bonnie, and LeofrancHolford-Strevens. The Oxford Companion to the Year: An Exploration of Calendar Customs and Time-Reckoning. Oxford: Oxford University Press, 1999.

Brunner, Borgna. "A Tale of Two Easters." Accessed 25 May 2014, http://www.factmonster.com/spot/easterl.html

“Chabad.org: Jewish/Civil Date Converter." Accessed 27 May 2014, http://www.chabad.org/calendar/1000year_cdo/aid/6225/jewish/Jew ish-Civil-Date-Converter.htm

Dionysius Exiguus. "Liber de Paschate Sive Cyclus Paschalis." Accessed 29 May 2014, http://hbar.phys.msu.ru/gorm/chrono/paschata.html

Dionysius Exiguus. "On Easter, or the Paschal Cycle." Pearse, Roger, ed. Early Church Fathers." Accessed 13 June 2014, http://www.tertullian. org/ fathers/dionysius_exiguus_easter_0l.htm

Duncan, David Ewing. The Calendar: Humanity's Epic Struggle to Determine a True and Accurate Year. London: Fourth Estate, 1999.

Encyclopaedia Judaica. 18 vols. Cecil Roth, ed. Jerusalem: Keter/Macmillan, 1978.

Hannah, Robert. Greek and Roman Calendars: Constructions of Time in the Classical World. London: Duckworth, 2005.

Hebcal Jewish Calendar. Accessed 28 May 2014, http:/hebcal.com/ converter.

Inter Gravissimus. Accessed 3 July 2014, http://www.bluewaterarts.com/ calendar/NewInterGravissimus.htm

Jaritz, Gerhard, and Gerson Moreno-Riano, eds. Time and Eternity: The Medieval Discourse. Brepols: Turnhout, 2003.

Migne, J. P., et. al., eds. Patrologia Latina. Patrologiaecursus completes: series Latina. 221 vols. Paris: 1844-1902.

Montes, Marcos J."The Orthodox Ecclesiastical Calendar." Accessed 25 April 2014, http://www.smart.net/-mmontes/ortheast.html

Mosshammer, Alden A. The Easter Computus and the Origins of the Christian Era. Oxford: Oxford University Press, 2008.

"Rosetta Calendar: A Calendar Conversion Service." Accessed 28 May 2014, http://www.rosettacalendar.com

Schukowski, Manfred, Uta Jahnke, and Wolfgang Fehlberg, eds. Mittelalterliche Astronomische Großuhren: Internationales Symposium in Rostock, 25. Bis 28. Oktober 2012. Leipzig: Akademische Verlagsanstalt, 2014. 
Steinmann, Andrew E. From Abraham to Paul: A Biblical Chronology. Saint Louis: Concordia Publishing House, 2011.

Stern, Sacha. Calendar and Community: A History of the Jewish Calendar, Second Century BCE to Tenth Century CE. Oxford: Oxford University Press, 2001.

"The Shepherd's Page: Calendar Stats." Accessed 28 May 2014, http://abdicate.net/cal.aspx

"Travel Wonders of the World: Touring the Mosaic City (Ravenna, Italy)." Accessed 28 May 2014, http://travel-wonders.com/2009 107/07/touring-the-mosaic-city-ravenna-italy-part-one/

Vardaman, Jerry, and Edwin M. Yamauchi, eds. Chronos, Kairos, Christos. Winona Lake, IN: Eisenbrauns, 1989.

Ware, Steven L. When Was Jesus Really Born?: Early Christianity, the Calendar, and the Life of Jesus. Saint Louis: Concordia Publishing House, 2013. 